\title{
Posterior rectus canal: not a single anatomical entity \& morphology - a laparoscopic study during TEP hernioplasty
}

\author{
Maulana Mohammed Ansari (iD) \\ Department of General Surgery, Jawaharlal Nehru Medical College, Aligarh Muslim University, Aligarh, India
}

\begin{abstract}
Objective: Posterior rectus canal assumed immense importance with newer laparoscopic technique of total extra-peritoneal pre-peritoneal (TEPP/ TEP) hernioplasty for inguinal hernia. However, scientific study of live surgical anatomy of posterior rectus canal is almost totally lacking in the English literature, and hence the present study was conducted.
\end{abstract}

Material and Methods: 3-midline-port technique through posterior rectus sheath approach; Initial telescopic dissection under direct $\mathrm{CO}_{2}$ insufflation followed by instrument dissection.

Results: 68 TEPP hernioplasties were successful in 60 patients with mean age of $50.1 \pm 17.2$ years (range 18-80) and mean BMl of $22.6 \pm 2.0 \mathrm{~kg} / \mathrm{m}^{2}(\mathrm{range}$ 19.5-31.2). Rectusial fascia was a definite anatomical entity, dividing traditional posterior rectus canal into two channels, namely, true retromuscular space and true posterior rectus canal (T-PRC). Rectusial fascia was variable, i.e., thick diaphanous $(n=47)$, thick membranous $(n=13)$, thin membranous $(n=3)$ and thin flimsy $(n=5)$. Posterior rectus sheath (PRS) was also variable, incomplete $(n=54)$ and complete $(n=14)$. Incomplete PRS showed seven variations in both extent and/or morphology. Complete PRS show five morphological variations. Transversalis fascia demonstrated three morphological variations, namely, single diaphanous $(n=41)$, single membranous $(=10)$ and thin flimsy $(n=3)$. TEPP hernioplasty was readily feasible through avascular true posterior rectus canal.

Conclusion: Posterior rectus canal is divided by 'rectusial fascia' into two channels, namely, true retromuscular space and true posterior rectus canal, latter being proper avascular plane of dissection for TEPP hernioplasty. Rectusial fascia, posterior rectus sheath and transversalis fascia showed morphological variations. Timely recognition of variable real-time anatomy is recommended to perform adequate proper surgical dissection for seamless TEPP hernioplasty with ease, rapidity and safety.

Keywords: Laparoscopic hernioplasty, total extraperitoneal preperitoneal hernioplasty, posterior rectus canal, rectusial fascia, posterior rectus sheath, transversalis fascia

Cite this article as: Ansari MM. Posterior rectus canal: not a single anatomical entity \& morphology - a laparoscopic study during TEP hernioplasty. Turk J Surg 2019; 35 (4): 299308 .

Corresponding Author

Maulana Mohammed Ansari

E-mail: mmansari.amu@gmail.com

Received: 19.10 .2018

Accepted: 27.03 .2019

Available Online Date: 16.12.2019

O Copyright 2019 by Turkish Surgical Society Available online at www.turkjsurg.com

DOI: $10.5578 /$ turkjsurg.4334

\section{INTRODUCTION}

In the modern era, posterior rectus canal has assumed an immense importance with the development of the newer laparoscopic technique of total extra-peritoneal pre-peritoneal (TEPP/TEP) hernioplasty through the posterior rectus approach for adult inguinal hernia. However, despite the current popularity of laparoscopic hernioplasty, scientific study of the live surgical anatomy of the posterior rectus canal is almost totally lacking in the English literature although acutely required because of the new preperitoneal perspective, high magnification with clear visualization of even thinnest fascial layers and recognition of newer visions of the structures, and need of the surgical precision in presence of the frequent anatomic variations (1-9). This paper highlights the laparoscopic live surgical anatomy of the posterior rectus canal as seen during the preperitoneal dissection for the laparoscopic TEPP hernioplasty of the primary inguinal hernias in adult patients.

\section{MATERIAL and METHODS}

Laparoscopic total extraperitoneal preperitoneal (TEPP) inguinal hernioplasty was performed in adult patients with uncomplicated primary inguinal hernia under the institutional ethical approval and informed consent at Jawaharlal Nehru Medical College Hospital, Aligarh Muslim University. A prospective doctoral research study was designed and prepared in April, 2010 to January, 2011, and surgery of laparoscopic hernioplasty was carried out from February, 2011 to November, 2015. 
Inclusion criteria included patients with age less than 18 years, uncomplicated primary inguinal hernia, absence of co-morbidity or presence of controlled mild co-morbidity (ASA grade I - II only of American Society of Anesthesiologists), and written informed consent. Exclusion criteria were refusal for laparoscopic repair, patient's age more than 18 years, presence of uncontrolled mild co-morbidity (ASA I and II), presence of severe co-morbidity (ASA grade III-IV), recurrent inguinal hernia after open or laparoscopic surgery, complicated inguinal hernia, presence of femoral or other groin hernia, and history of previous lower abdominal surgery. Calculation of the body mass index (BMI) was done by Deurenberg's formula (10).

Laparoscopic TEPP inguinal hernioplasty was performed through posterior rectus sheath approach with three ports in the midline. Balloon dissector made of a surgical glove was used for the initial dissection within the posterior rectus canal in the first three patients of the study, and the direct telescopic dissection was carried under $\mathrm{CO}_{2}$ insufflation at a pressure of 12 $\mathrm{mmHg}$ in the remaining patients of the study. Details of the surgical technique were consistently the same as reported earlier by the author (4,8,9,11-17).

\section{Statistical Analysis}

Most of the statistical computations for the author's doctoral thesis for the award of degree of PhD (Surgery) were performed with the help of SPSS software v. 21 (IBM SPSS Statistics 21.0, USA)) after coding the patients' data and recording in the Microsoft excel spread sheet. Help for some simple statistical analysis was also taken from the On-line Calculators (www.graphad. com/quickcalcs/; www.danielsoper.com/statcalc/). All data analysis was expressed in terms of mean \pm s.d. (standard deviation) unless specified otherwise, and a $p$-value of $<0.05$ was considered as significant.

\section{RESULTS}

Sixty-three adult males and 3 adult females with uncomplicated primary inguinal hernia were recruited for the study. The three female patients who could not undergo TEPP hernioplasty due to one or more exclusion criteria were excluded from the study. Three male patients who had early forced conversion (Laparoscopic transabdominal repair, 1; Open preperitoneal repair, 1; and Open anterior repair, 1) were also excluded from the study. The cause for the conversion included early peritoneal injury by the 1st optical port, early vascular injury (deep inferior epigastric vessels) by the roughened Maryland dissector, and $\mathrm{CO}_{2}$ retention with haemodynamic instability just after start of the procedure due to faulty selection of patient. Therefore, the data analysis includes 68 successful TEPP hernioplasties (Unilateral TEPP, 52; Bilateral TEPP, 8) performed in only 60 male patients. Mean age was $50.1 \pm 17.2$ years (range 1880 ), and mean BMl was $22.6 \pm 2.0 \mathrm{~kg} / \mathrm{m}^{2}$ (range 19.3-31.2).

Under excellent perspective, lighting and magnification of preperitoneal laparoscopy through posterior rectus sheath ap- proach with direct telescopic dissection under $\mathrm{CO} 2$ insufflation, the posterior epimysium of the rectus abdominis muscle was found as a variably condensed and easily recognizable fascial layer which was termed the 'Rectusial Fascia' by the author (Fig. 2) (4). Rectusial fascia was found well-defined thickened in 60 out of 68 cases (Thick Diaphanous, 47; Thick Membranous, 13) and thin flimsy in 8 cases (Thin Membranous, 3; Thin Flimsy, 5) (Table 1) (Figure 1-4). This 'rectusial fascia was found to divide the traditional posterior rectus canal between the rectus abdominis muscle and the posterior rectus sheath into two potential spaces/channels, namely, (1) a true retromuscular space (RMS) anterior to the rectusial fascia, and (2) a true posterior rectus canal (TPRC) posterior to the rectusial fascia (Figure 5-7). Thus the retromuscular space (RMS) was bounded anteriorly by the rectus abdominis muscle and posteriorly by the rectusial fascia; and the true posterior rectus canal (TPRC) was bounded anteriorly by the rectusial fascia and posteriorly by a complete posterior rectus sheath upto the pubic bone only $(n=14)$ (Figure 1,3-7,11-14). or by an incomplete posterior rectus sheath in upper part and transversalis fascia in lower part $(n=54)$ (Figure 2,8-10).

The plane of retrofascial dissection posterior to the rectusial fascia in the 'true posterior rectus canal' (TPRC) was found avascular proper surgical plane for further dissection during the TEPP hernioplasty, and inadvertent/deliberate pre-fascial dissection anterior to the rectusial fascia in the retromuscular space (RMS)

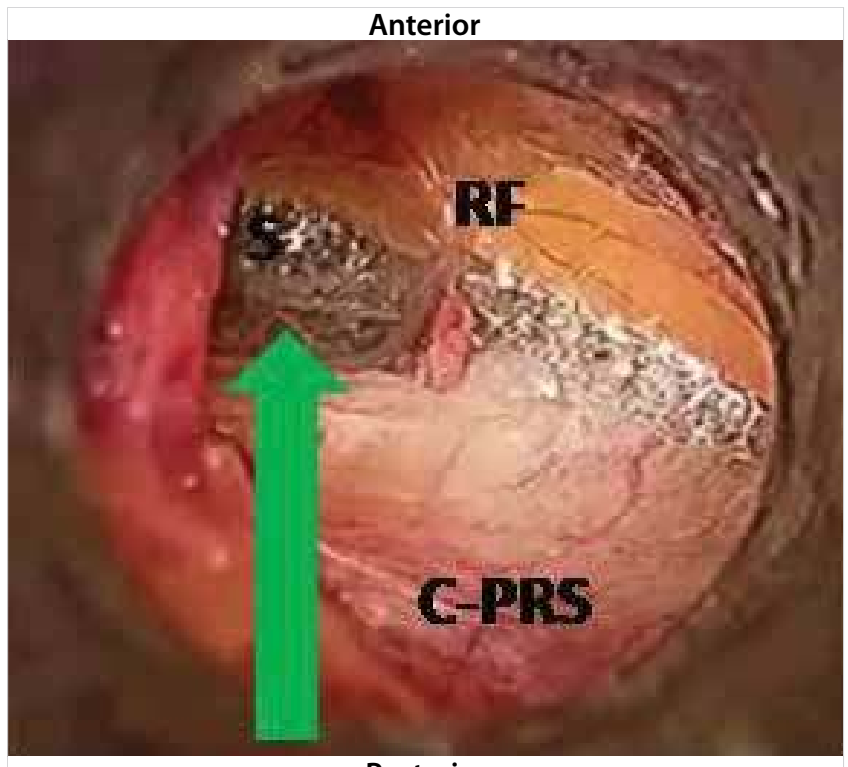

\section{Posterior}

Figure 1. Boundaries of True Posterior Rectus Canal observed during Laparoscopic Total Extraperitoneal Preperitoneal (TEPP) Hernioplasty An Adult Patient: Green Arrow, indicates true posterior rectus canal; RF, thick diaphanous rectusial fascia forming anterior boundary of true posterior rectus canal; C-PRS, whole-tendinous complete posterior rectus sheath (C-PRS) forming posterior boundary of true posterior rectus canal; $\mathrm{S}$, sign of lighthouse; (Reproduced with permission from Ansari's Thesis (13). 
Table 1. Morphological types of rectusial fascia forming anterior boundary of true posterior rectus canal

\begin{tabular}{|c|c|c|c|c|c|}
\hline \multirow[b]{2}{*}{ S. No. } & \multirow[b]{2}{*}{ Rectusial Fascia } & \multicolumn{2}{|c|}{ Hernias* } & \multicolumn{2}{|c|}{ Patients } \\
\hline & & $\mathbf{N}$ & $\%$ & $\mathrm{~N}$ & $\%$ \\
\hline 1. & Thick Diaphanous & 47 & 69.1 & 41 & 68.3 \\
\hline 2. & Thick Membranous & 13 & 19.1 & 12 & 20.0 \\
\hline 3. & Thin Membranous & 3 & 4.4 & 3 & 5.0 \\
\hline \multirow[t]{2}{*}{4.} & Thin Flimsy & 5 & 7.4 & 4 & 6.7 \\
\hline & Total & 68 & 100 & 60 & 100 \\
\hline
\end{tabular}

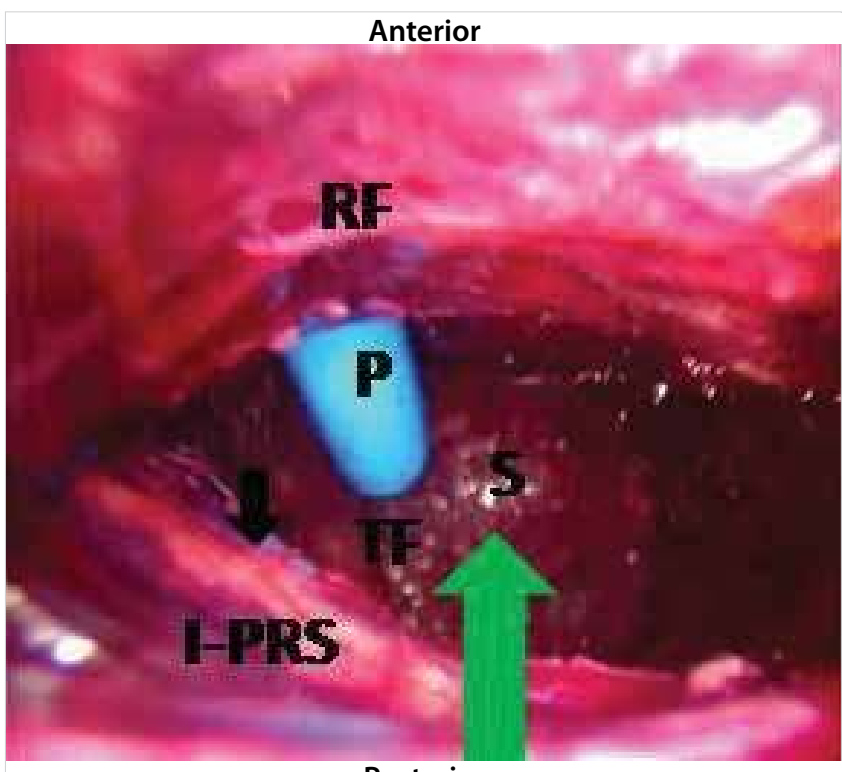

Posterior

Figure 2. Boundaries of True Posterior Rectus Canal observed during Laparoscopic Total Extraperitoneal Preperitoneal (TEPP) Hernioplasty An Adult Patient: Green Arrow, indicates true posterior rectus canal; RF, thick membranous rectusial fascia forming anterior boundary of true posterior rectus canal; C-PRS, long tendinous incomplete posterior rectus sheath (I-PRS) forming posterior boundary of true posterior rectus canal; TF, transversalis fascia; $S$, sign of light house; $P$, working port (blue plastic); (Reproduced with permission from Ansari's Thesis (13).

was found bloody with several disadvantages as reported earlier by the author (14).

Posterior boundary of the true posterior rectus canal (TPRC) was also found highly variable in morphology as reported earlier by the author (Figure 1,3-7,11-15) (8,9). Complete posterior rectus sheath (C-PRS) forming the posterior boundary of the T-PRC was found whole-tendinous (CWT, 6), whole-thinned-out (CTO, 3), grossly-attenuated (CGA, 3), musculo-tendinous (CMT, 1), partly-tendinous (CPT, 1) (Table 2). Incomplete posterior rectus sheath (IC-PRS) was also found variable in morphology, namely, normal-length whole tendinous (NWT, 31), normal-length partly tendinous (NPT, 8), short whole-tendinous (SWT, 3), normal-length thinned-out (NTO, 1), normal-length grossly-attenu-

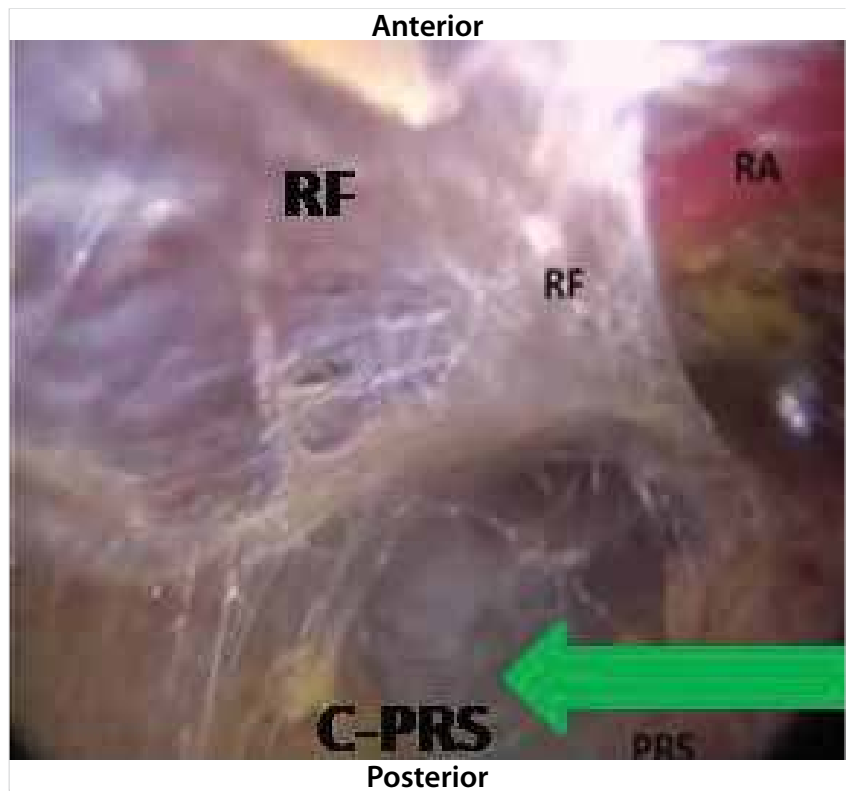

Figure 3. Boundaries of True Posterior Rectus Canal observed during Laparoscopic Total Extraperitoneal Preperitoneal (TEPP) Hernioplasty in An Adult Patient: Green Arrow, indicates true posterior rectus canal; $\mathrm{RF}$, thin membranous rectusial fascia forming anterior boundary of true posterior rectus canal; C-PRS, membranous complete posterior rectus sheath (C-PRS) forming posterior boundary of true posterior rectus canal; RA, rectus abdominis muscle covered by rectusial fascia (RF); (Reproduced with permission from Ansari's Thesis (13).

ated (NGA, 1), long partly-tendinous (LPT, 7) and long whole-tendinous (LWT, 3) (Table 2).

When the posterior rectus sheath (PRS) was complete $(n=14)$ (Figure 2,3,6), it directly formed the posterior wall of the true posterior rectus canal. However, in presence of an incomplete PRS $(n=54)$ (Figure 2,8-10), the lower posterior wall of the true posterior rectus canal was formed by the transversalis fascia, and the morphology of the transversalis fascia was also found variable, namely, single diaphanous, i.e., single membranous with significant fibro-fatty tissues on its outer side (SD, 41); single membranous with little/no fatty tissue on its outer side (SM, 10), and thin flimsy (FL, 3) (Table 3). 


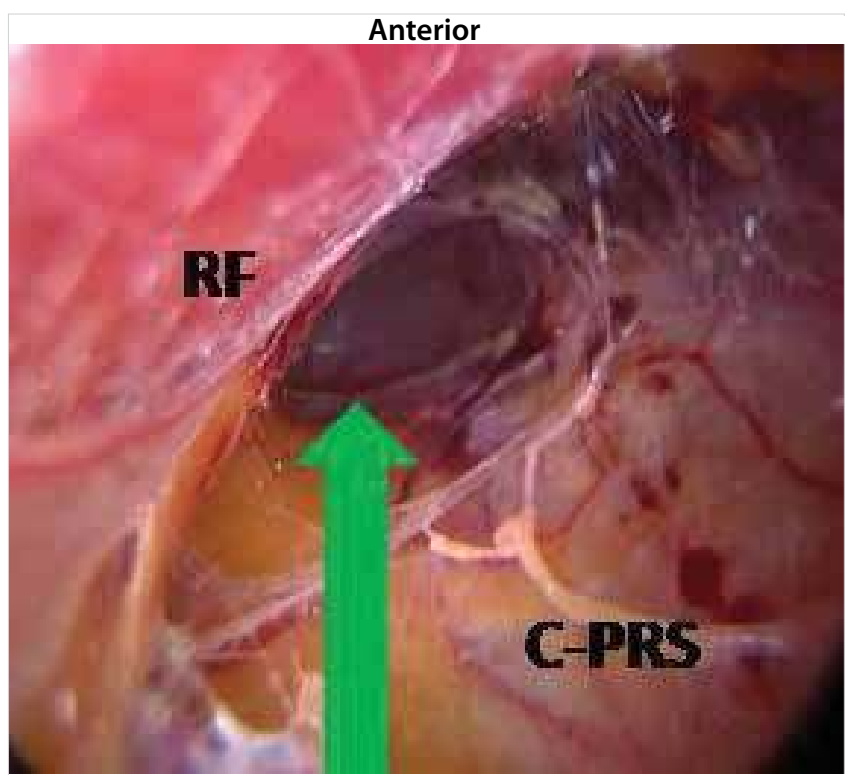

Posterior

Figure 4. Boundaries of True Posterior Rectus Canal observed during Laparoscopic Total Extraperitoneal Preperitoneal (TEPP) Hernioplasty in An Adult Patient: Green Arrow, indicates true posterior rectus canal; RF, thin flimsy rectusial fascia forming anterior boundary of true posterior rectus canal; C-PRS, membranous complete posterior rectus sheath (CPRS) forming posterior boundary of true posterior rectus canal; (Reproduced with permission from Ansari's Thesis (13).

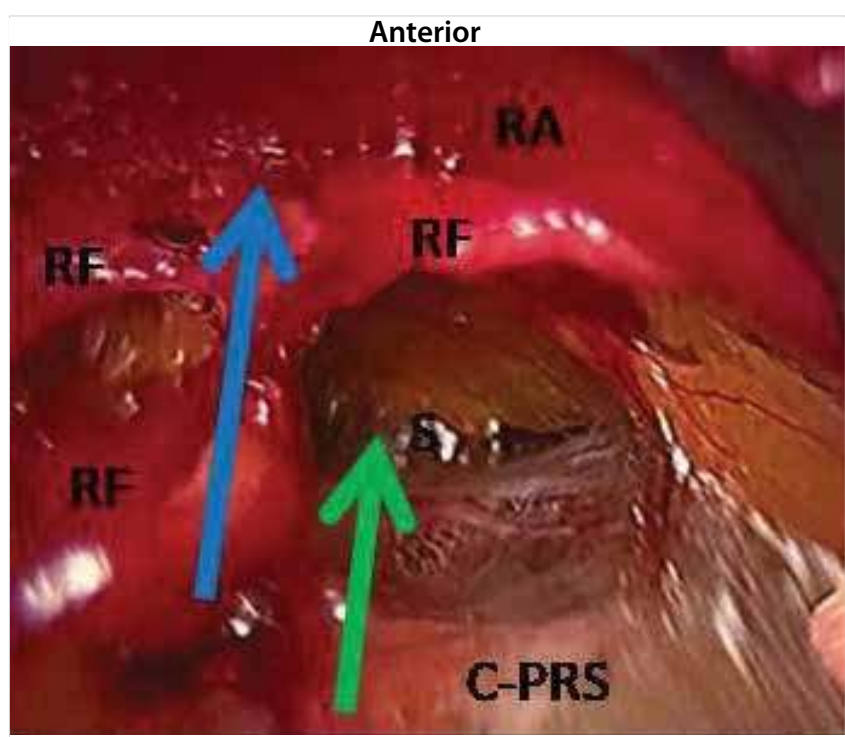

Posterior

Figure 5. Double-Channelled Posterior Rectus Canal observed during Laparoscopic Total Extraperitoneal Preperitoneal (TEPP) Hernioplasty in An Adult Patient: Green Arrow, indicates true posterior rectus canal between thick diaphanous rectusial fascia (RF) and grossly-attenuated complete posterior rectus sheath (C-PRS); Blue Arrow, indicates true retromuscular space between rectus abdominis muscle (RA) and thick diaphanous rectusial fascia (RF); S, sign of lighthouse; (Reproduced with permission from Ansari's Thesis (13).

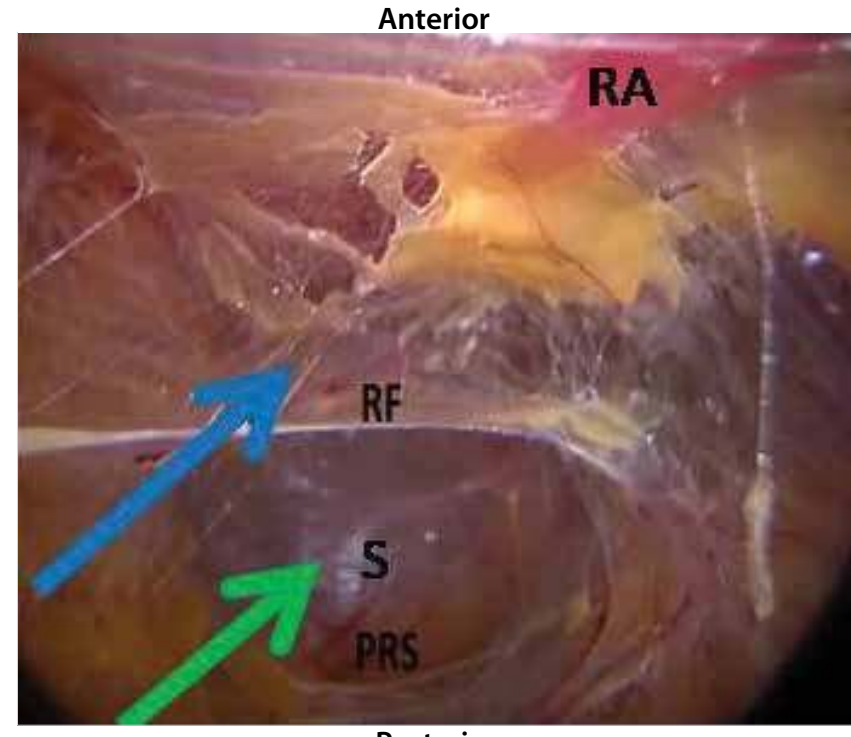

Posterior

Figure 6. Double-Channelled Posterior Rectus Canal observed during Laparoscopic Total Extraperitoneal Preperitoneal (TEPP) Hernioplasty in An Adult Patient: Green Arrow, indicates true posterior rectus canal between thin membranous rectusial fascia (RF) and membranous complete posterior rectus sheath (C-PRS); Blue Arrow, indicates true retromuscular space between rectus abdominis muscle (RA) and thin membranous rectusial fascia (RF); S, sign of lighthouse; (Reproduced with permission from Ansari's Thesis (13).

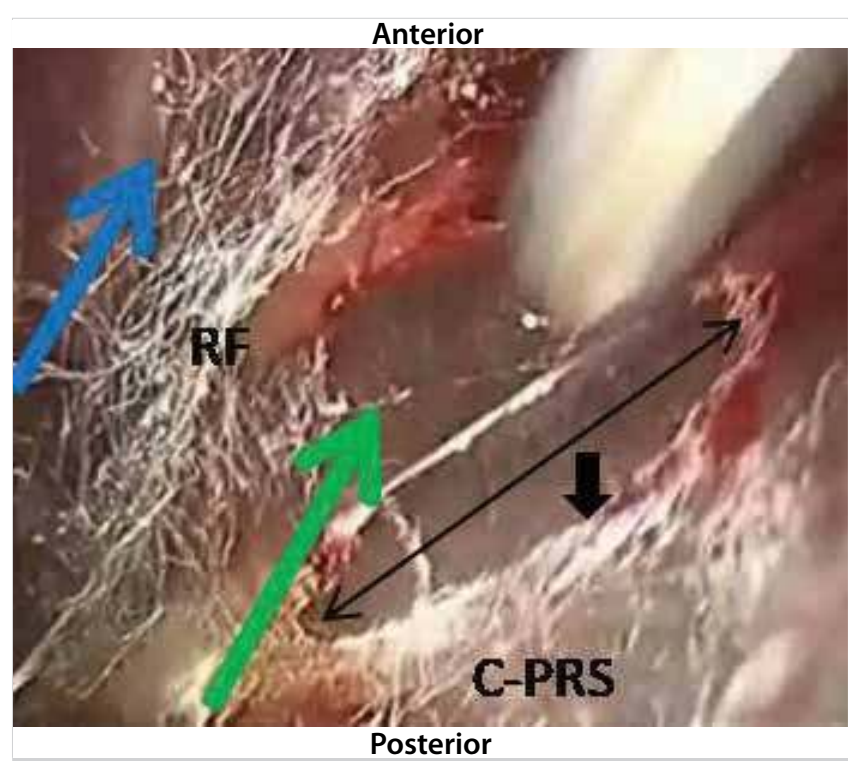

Figure 7. Double-Channelled Posterior Rectus Canal Observed during Laparoscopic Total Extraperitoneal Preperitoneal (TEPP) Hernioplasty in An Adult Patient: Green Arrow, indicates true posterior rectus canal between thin flimsy rectusial fascia (RF) and membranous complete posterior rectus sheath (C-PRS); Blue Arrow, indicates true retromuscular space between rectus abdominis muscle (RA) and thin flimsy rectusial fascia (RF); S, sign of lighthouse; Double-Headed Black Arrow, indicates opening made in complete posterior rectus sheath (PRS); Single-Head Black Arrow, indicates artificial arcuate line created in complete posterior rectus sheath (C-PRS); (Reproduced with permission from Ansari's Thesis (13). 


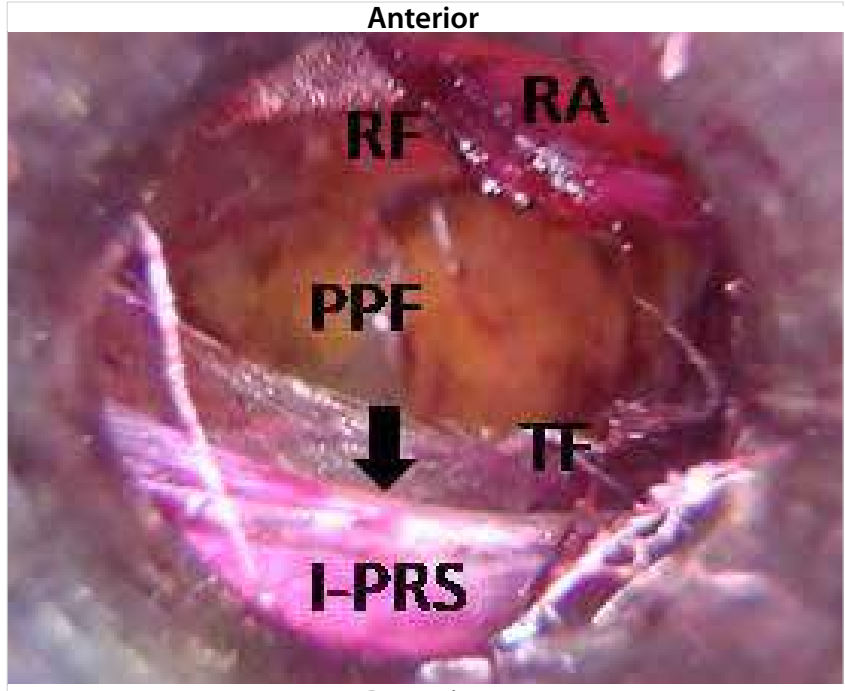

Posterior

Figure 8. True Posterior Rectus Canal observed during Laparoscopic Total Extraperitoneal Preperitoneal (TEPP) in An Adult Patient: I-PRS, tendinous incomplete posterior rectus sheath with well-defined arcuate line (Black arrow); RF, well-formed membranous rectusial fascia covering partly-visible rectus abdominis muscle (RA); TF, transversalis fascia; PPF, preperitoneal fascia; (Reproduced with permission from Ansari's Thesis (13).

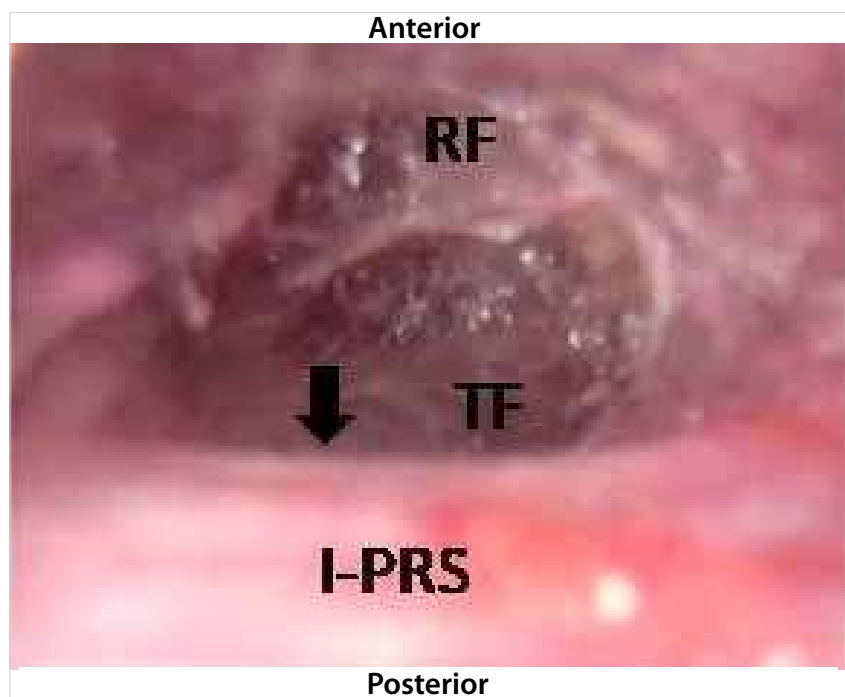

Figure 9. True Posterior Rectus Canal observed during Laparoscopic Total Extraperitoneal Preperitoneal (TEPP) in An Adult Patient: I-PRS, tendinous incomplete posterior rectus sheath with well-defined arcuate line (Black arrow); RF, well-formed membranous rectusial fascia covering rectus abdominis muscle (not visible); TF, transversalis fascia; (Reproduced with permission from Ansari's Thesis (13).

Deep inferior epigastric vessels (DIEV) were found running always in the retromuscular space supplying both the rectus muscle and its variably condensed posterior epimysium (rectusial fascia). In patients with incomplete posterior rectus sheath

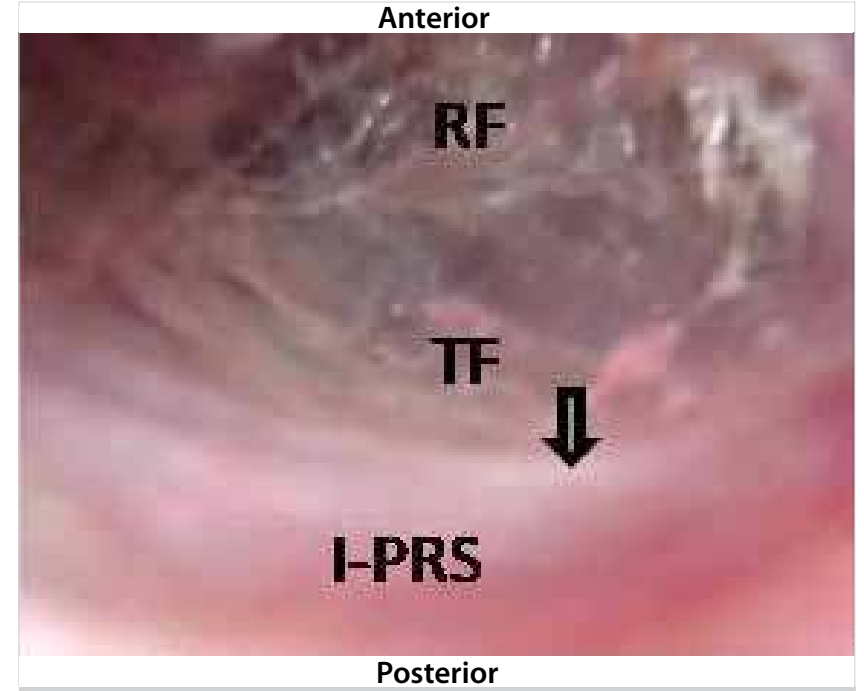

Figure 10. True Posterior Rectus Canal observed during Laparoscopic Total Extraperitoneal Preperitoneal (TEPP) in An Adult Patient: I-PRS, partly tendinous (upper part tendinous and lower part attenuated) incomplete posterior rectus sheath with indistinct arcuate line (Truncated black arrow); RF, well-formed membranous rectusial fascia covering rectus abdominis muscle (not visible); TF, transversalis fascia; (Reproduced with permission from Ansari's Thesis (13).

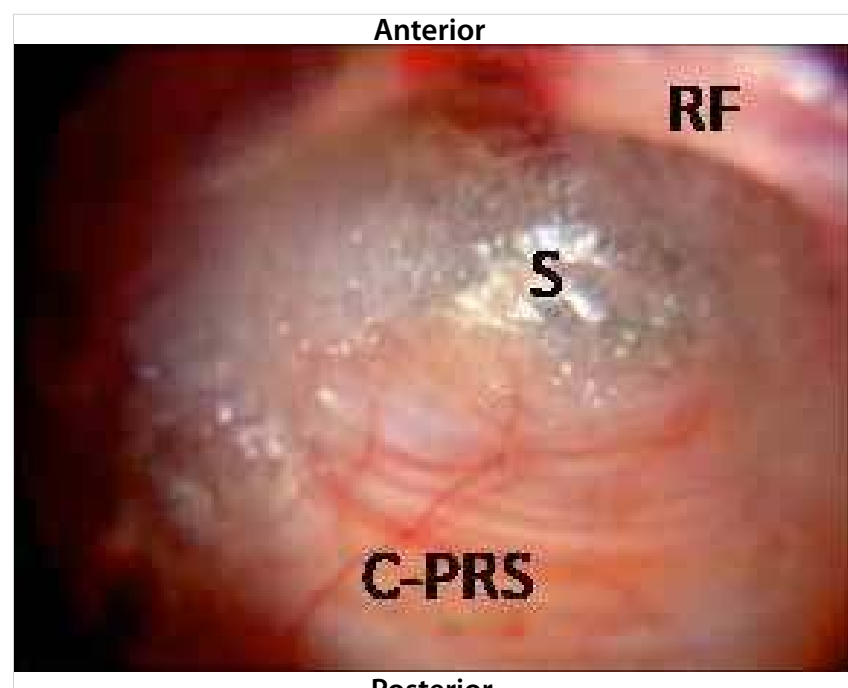

\section{Posterior}

Figure 11. True Posterior Rectus Canal observed during Laparoscopic Total Extraperitoneal Preperitoneal (TEPP) in An Adult Patient: C-PRS, whole-tendinous complete posterior rectus sheath with absent arcuate line; RF, thick membranous rectusial fascia covering rectus abdominis muscle (not visible); S, sign of lighthouse; (Reproduced with permission from Ansari's Thesis (13).

(PRS), the DIEV, was initially running within the transversalis fascia and then entered the retromuscular space by piercing the rectusial fascia above the arcuate line. In patients with the complete PRS $(8,9,15)$, the DIEV was found to course within the retromuscular space from just above the symphysis pubis. 


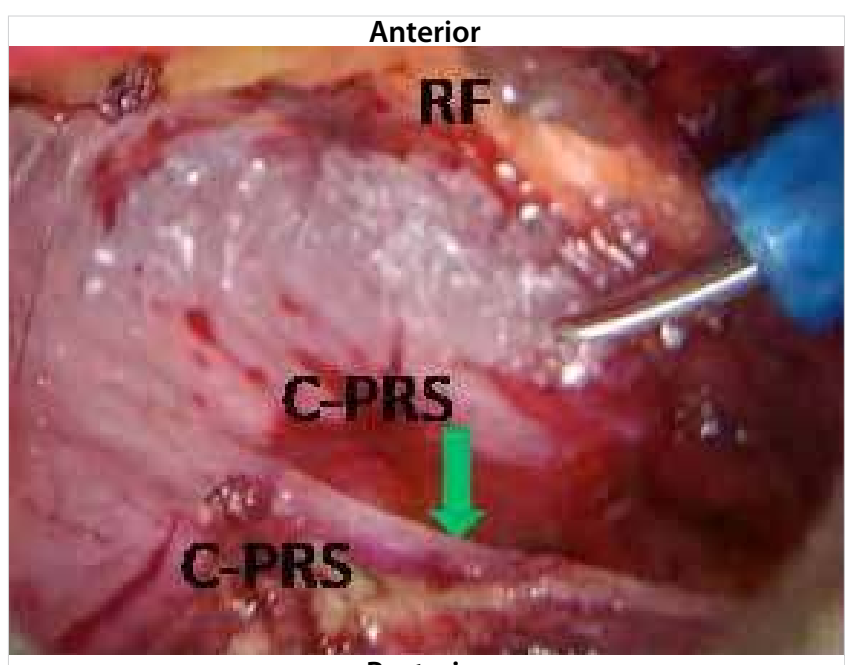

Posterior

Figure 12. True Posterior Rectus Canal observed during Laparoscopic Total Extraperitoneal Preperitoneal (TEPP) in An Adult Patient: C-PRS, membranous complete posterior rectus sheath with a secondary arcuate line (green arrow); RF, thick diaphanous rectusial fascia covering rectus abdominis muscle (not visible); (Reproduced with permission from Ansari's Thesis (13).

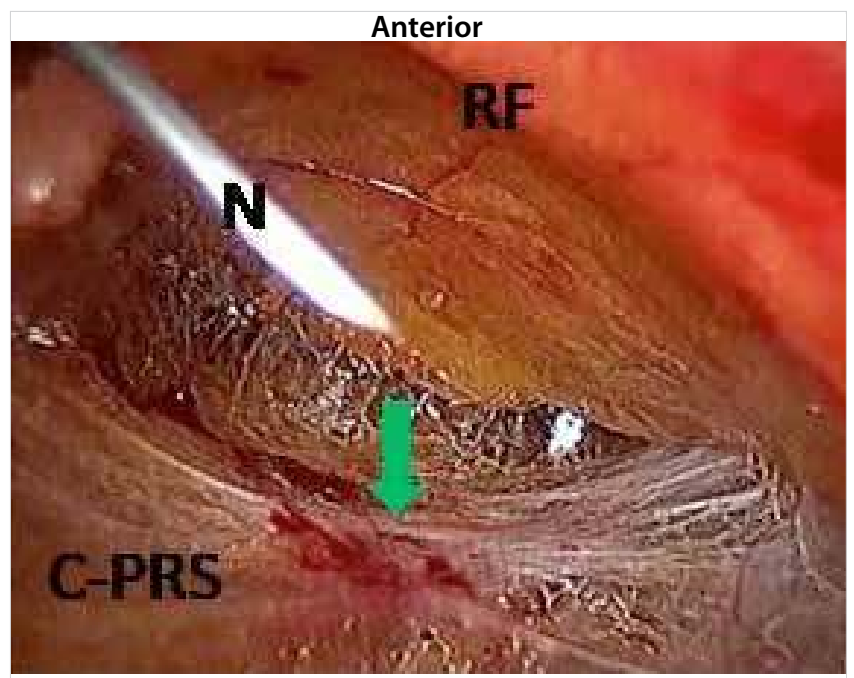

Posterior

Figure 13. True Posterior Rectus Canal observed during Laparoscopic Total Extraperitoneal Preperitoneal (TEPP) in An Adult Patient: C-PRS, grossly-attenuated complete posterior rectus sheath with Henle's Band (green arrow) which is regarded as a secondary arcuate line; RF, thick diaphanous rectusial fascia covering rectus abdominis muscle (not visible); N, hypodermic needle inserted percutaneously for confirmation of axis and depth before placement of working port; (Reproduced with permission from Ansari's Thesis (13).

\section{DISCUSSION}

Way back in 1942, Baumann stated that "One might think that the science of anatomy has completed the detailed description of the human body ... However, some structures are still prob-

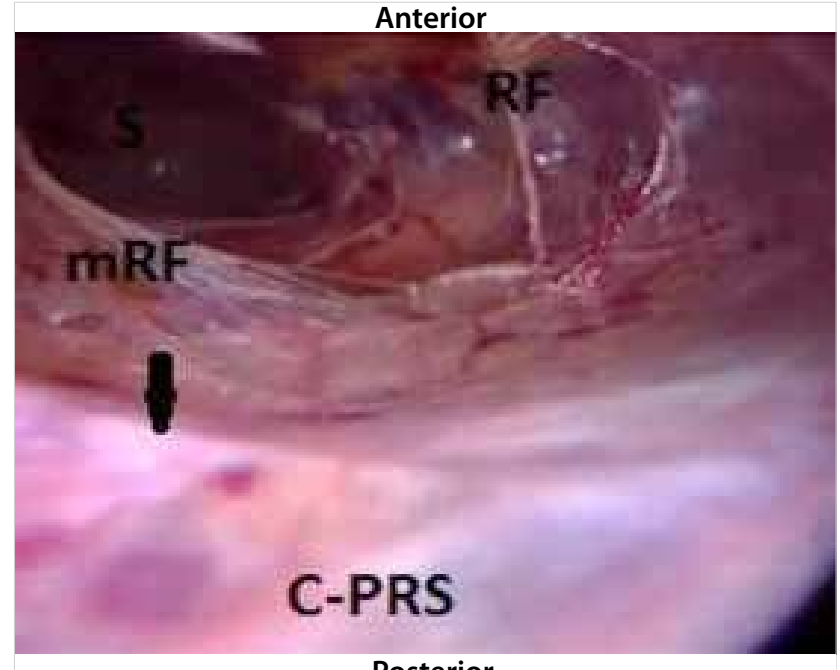

Posterior

Figure 14. True Posterior Rectus Canal observed during Laparoscopic Total Extraperitoneal Preperitoneal (TEPP) in An Adult Patient: C-PRS, membranous complete posterior rectus sheath with a secondary arcuate line (black arrow); RF, membranous rectusial fascia covering rectus abdominis muscle (not visible); mRF, part of rectusial fascia taken down with the posterior rectus sheath and initially misidentified as transversalis fascia as reported earlier by the author (12); (Reproduced with permission from Ansari's Thesis (13).

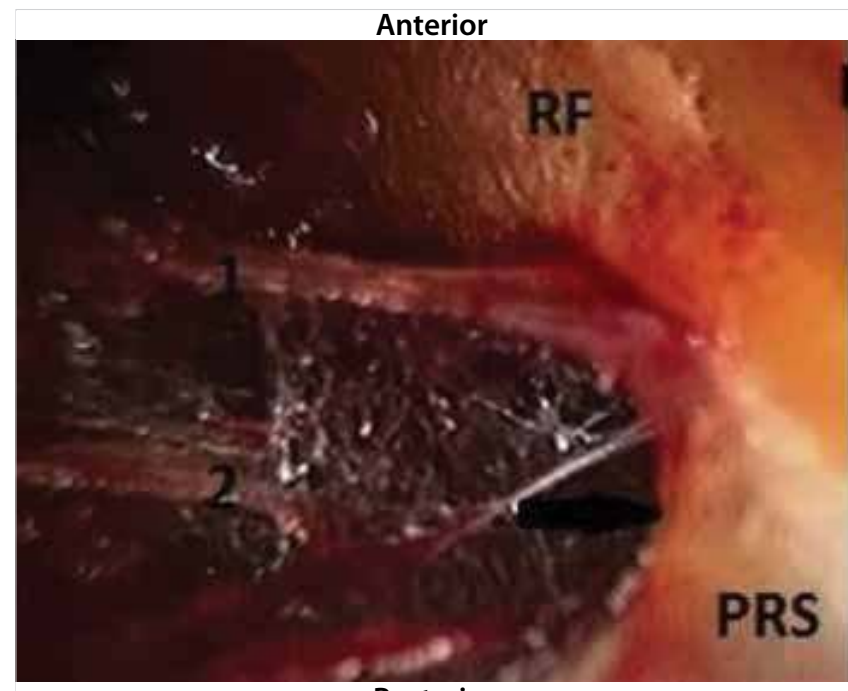

\section{Posterior}

Figure 15. Double-Layered Complete Posterior Rectus Sheath in an Adult Patient Undergoing Laparoscopic Total Extraperitoneal Preperitoneal (TEPP) Hernioplasty: RF, thick diaphanous rectusial fascia covering rectus abdominis muscle (not visible); PRS, complete posterior rectus sheath with creation of artificial arcuate line in progress; 1 and 2, two layers of posterior rectus sheath, the deeper layer being initially misidentified for a moment as transversalis fascia as reported earlier by the author (11); (Reproduced with permission from Ansari's Thesis (13).

lems..." (18). Baumann's statement was ratified as lately as 1997 by Diarra even after the advent of CT, MRI and laparoscopy (19). Despite general accord, the traditional textbook description of 
Table 2. Morphological types of posterior rectus sheath forming posterior boundary of true posterior rectus canal

\begin{tabular}{|c|c|c|c|c|c|c|}
\hline \multirow[b]{2}{*}{ S. No. } & \multirow[b]{2}{*}{ PRS Type } & \multirow[b]{2}{*}{ PRS Subtype } & \multicolumn{2}{|c|}{ Hernias } & \multicolumn{2}{|c|}{ Patients } \\
\hline & & & $\mathbf{N}$ & $\%$ & $\mathbf{N}$ & $\%$ \\
\hline 1. & \multirow[t]{5}{*}{ Complete PRS } & CWT & 6 & 16.2 & 6 & 18.2 \\
\hline 2. & & СTO & 3 & 8.1 & 3 & 9.1 \\
\hline 3. & & CGA & 3 & 8.1 & 3 & 9.1 \\
\hline 4. & & CMT & 1 & 2.7 & 1 & 3.0 \\
\hline 5. & & CPT & 1 & 2.7 & OS & - \\
\hline 6. & \multirow[t]{7}{*}{ Incomplete PRS } & NWT & 31 & 45.6 & 27 & 45.00 \\
\hline 7. & & NPT & 8 & 21.6 & 7 & 21.2 \\
\hline 8. & & SWT & 3 & 8.1 & 3 & 9.1 \\
\hline 9. & & NTO & 1 & 2.7 & 1 & 3.0 \\
\hline 10. & & NGA & 1 & 2.7 & OS & - \\
\hline 11. & & LPT & 7 & 18.9 & 7 & 21.2 \\
\hline \multirow[t]{2}{*}{12.} & & LWT & 3 & 8.1 & 2 & 6.1 \\
\hline & & Total & 68 & 100 & 60 & 100 \\
\hline
\end{tabular}

PRS: Posterior rectus sheath, CWT: Complete whole-tendinous, CTO: Complete thinned-out, CGA: Complete grossly attenuated, CMT: Complete musculo-tendinous, CPT: Complete partly-tendinous, NWT: Normal-length whole-tendinous, NPT: Normal-length partly tendinous, SWT: Short whole-tendinous, NTO: Normal-length thinned-out, NGA: Normal-length grossly attenuated, LWT: Long whole-tendinous, LPT: Long partly-tendinous.

Table 3. Morphological types of transversalis fascia forming lower posterior boundary of true posterior rectus canal in patients with incomplete $\operatorname{PRS}(n=54)$

\begin{tabular}{|l|c|c|c|c|c|}
\hline \multirow{2}{*}{ S. No. } & & \multicolumn{2}{|c|}{ Hernias* } & \multicolumn{2}{|c|}{ Patients } \\
\hline 1. & Transversalis Fascia & N & \% & N & 78 \\
\hline 2. & SD & 41 & 75.9 & 8 & 16.3 \\
\hline 3. & SM & 10 & 18.5 & 3 & 6.1 \\
\hline & FL & 3 & 5.7 & $\mathbf{4 9}$ & $\mathbf{1 0 0}$ \\
\hline
\end{tabular}

PRS: Posterior rectus sheath, SD: Single diaphanous (single membranous with significant fibro-fatty tissues on its outer side); SM: Single membranous with little/no fatty tissue on its outer side; FL, thin flimsy.

the rectus sheath formation is not a common arrangement in the opinion of several investigators since long (20-22). Even in 1940, McVay and Anson really commented that "Descriptions of the rectus sheath contained in our textbooks of anatomy are singularly alike; they are stereotyped and oversimplified" (21).

Traditionally, the rectus abdominis muscle is said to be enclosed within a fibrous rectus sheath, with an anterior rectus sheath (ARS) being tendinous and complete extending upto the pubic bone but with a posterior rectus sheath (PRS) being tendinous and incomplete ending below the umbilicus with a well-defined sharp Arcuate Line at $1 / 4$ th to $1 / 2$ of the umbilico-pubic distance and not extending upto the pubic bone. Posterior rectus canal, currently the most preferred approach for the laparoscopic total extraperitoneal preperitoneal (TEPP) hernioplasty for the inguinal hernia, is traditionally taught to be bounded anteriorly by the fleshy rectus abdominis muscle and bounded posteriorly by the incomplete aponeurotic posterior rectus sheath in up- per part and the transversalis fascia in the lower part. Under excellent lighting and magnification of modern laparoscopy, not only new structures/tissue planes and phenomena have been discovered (2,4,8,9,11-17,23-25), but also the frequent anatomic variations often reported in the previous cadaveric studies were confirmed (7,26-31), which are visualized too clearly to refute even against the prior fixed mindset based on the traditional anatomy classroom teaching (2), although they rarely received the attention of the authors of the traditional textbooks of surgery \&/or anatomy commonly read by the medical students. Current bilaminar/trilaminar concept of the posterior rectus sheath in cadaveric studies $(27,30,32)$ is supported by the laparoscopic live anatomical findings of double-/multi-layered posterior rectus sheath (Figure 15) $(9,23)$.

In the modern era, the posterior rectus canal has assumed an immense importance with the development of the newer laparoscopic technique of total extra-peritoneal pre-peritoneal 
(TEPP/TEP) hernioplasty through the posterior rectus approach for the adult inguinal hernia because of the four important reasons, viz., Firstly, "Inguinal anatomy as viewed through the laparoscope is unfamiliar to most surgeons" (1); Secondly, " new surgical techniques provide new vision of structures known for centuries" (3), for example, the 'rectusial fascia', a definite laparoscopic anatomical entity of great surgical importance during TEPP hernioplasty $(4,14)$; Thirdly, very little research is reported in the recent literature regarding the laparoscopic inguinal hernia anatomy many of which lacks anatomical precision (5), and the available material belongs to mainly gross anatomy of cadaveric nature which is often misleading due to embalming-induced hardening, distortion, and fusion of the fascial layers (6,33); Fourthly, wide anatomic variations in the posterior rectus sheath known to occur since the time (1804 AD) of Sir Astley Cooper (34) were re-emphasized by several investigators in recent years but which received little/no attention of not only the anatomists but also the practicing surgeons (7).

As the posterior rectus sheath is often grossly attenuated (9) and fascia-like (Rectus Sheath Fascia of Arregui) $(2,35)$, an adequate and proper preperitoneal dissection for preperitoneal mesh repair (open as well as laparoscopic) depends on an accurate understanding of these fasciae (2). Moreover, timely recognition of the variability of the preperitoneal fascial structures is really important for the success of a seamless laparoscopic hernia repair with better outcomes $(2,36)$.

To conclude, the present laparoscopic study confirmed the age-old opinion of McVay and Anson (21) that the traditional textbook description of the posterior rectus canal formation is oversimplified and stereotyped, and the real-time surgical anatomy is often distinctly different from patient to patient. Traditional posterior rectus canal is not really a single anatomical entity but divided by a newly-discovered 'rectusial fascia' into two distinct potential spaces/channels of great surgical importance during the laparoscopic TEPP hernioplasty, namely, a true retromuscular space and a true posterior rectus canal, the latter being the proper avascular surgical plane of dissection for the TEPP hernioplasty. Present study also confirmed the frequent morphological variations in both the rectusial fascia and the posterior rectus sheath which form the anterior and posterior boundaries of the true posterior rectus canal respectively.

\section{Study Limitations}

The present study had four limitations. Firstly, sample size of 68 hernioplasties in the present study was rather small in the light of such a common problem of inguinal hernia, and reasons for this included patient reluctance for newer surgical technique, peer reluctance for laparoscopic TEPP hernioplasty due to the demanding nature of the procedure and increased operating time, and higher cost; and therefore a larger cohort sample ap- pears necessary to validate many of our observations. Secondly, the study included male patients only because of two reasons, i.e., uncommon incidence of inguinal hernia in females and exclusion of the three initially-recruited female patients due to exclusion criteria of the study. Thirdly, the author could not enlist the services of a dedicated anatomist inside the operation theatre for validation and easy recognition of tissues/structures and their morphological variations. Fourthly, the study was conducted with 3-chip endo-camera, and the availability of a high definition endovision might have improved our observations.

\section{CONCLUSION}

Traditional posterior rectus canal is not really a single anatomical entity but divided by a newly-discovered 'rectusial fascia' into two distinct potential spaces/channels of great surgical importance during laparoscopic TEPP hernioplasty, namely, (1) a true retromuscular space (RMS) anterior to the rectusial fascia, and (2) a true posterior rectus canal (TPRC) posterior to the rectusial fascia, the latter being the proper avascular surgical plane of dissection for the TEPP hernioplasty. Present study also confirmed frequent morphological variations in both the rectusial fascia and the posterior rectus sheath which form the anterior and posterior boundaries of the true posterior rectus canal respectively, requiring astute attention of the laparoscopic TEPP surgeons for timely recognition of the variable real-time anatomy in order to perform an adequate and proper surgical dissection through the avascular true posterior rectus canal for the seamless TEPP hernioplasty with ease, rapidity and safety.

Ethics Committee Approval: Obtained from the Institutional Ethics Committee of the Faculty of Medicine, Aligarh Muslim University, India (\#770/21.08.2013).

Informed Consent: Written informed consent was obtained from patients who participated in this study.

Peer-review: Externally peer-reviewed.

Author Contributions: Concept - M.M.A.; Design - M.M.A.; Supervision M.M.A.; Resource - M.M.A.; Materials - M.M.A.; Data Collection and/or Processing - M.M.A.; Analysis and/or Interpretation - M.M.A.; Literature Search - M.A.; Writing Manuscript - M.M.A.; Critical Reviews - M.M.A.

Conflict of Interest: The authors have no conflicts of interest to declare.

Financial Disclosure: The authors have no conflicts of interest to declare.

\section{REFERENCES}

1. Spaw AT, Ennis BW, Spaw LP. Laparoscopic hernia repair: the anatomic basis. J Laparoendoscop Surg 1991;1:269-77. [CrossRef]

2. ArreguiME. Surgical anatomy of the pre-peritoneal fasciae and posterior transversalis fasciae in the inguinal region. Hernia 1997;1:101-10. [CrossRef]

3. Avisse C, Delattre JF, Flament JB. The inguinofemoral area from a laparoscopic standpoint. History, anatomy, and surgical applications. Surg Clin North Am 2000;80(1):35-48. [CrossRef] 
4. Ansari MM. Rectusial fascia: a new entity of laparoscopic live surgical anatomy. Open Access J Surg 2017;3(4):1-5.[CrossRef]

5. Colborn GL, Skandalakis JE. Laparoscopic inguinal anatomy. Hernia 1998:2:179-91.[CrossRef]

6. Memon MA, Quin TH, Cahill DR. Transversalis fascia: historical aspects and its place in contemporary inguinal herniorrhaphy. J Laproendoscop Adv Surg Tech 1999;9(3):267-72.[CrossRef]

7. Mwachaka P, Odula P, Awori K, Kaisha. Variations in the pattern offormation of the abdominis rectus muscle sheath among Kenyans. Int J Morphol 2009;27(4):1025-9.[CrossRef]

8. Ansari MM. Posterior rectus sheath variations: surgical significance and clinical implications for laparoscopic hernia surgeons. Int Surg J 2018;5(2):683-94. [CrossRef]

9. Ansari MM. Posterior rectus sheath: a prospective study of laparoscopic live surgical anatomy during TEPP hernioplasty. World J LaparosC Surg 2018;11(1):12-24. [CrossRef]

10. Deurenberg P, Weststrate JA, Seidell JC. Body mass index as a measure of fatness: age- and sex-specific prediction formulas. Br J Nutr 1991;65:105-14.[CrossRef]

11. Ansari MM. Optical illusions quintuple during laparoscopic total extraperitoneal preperitoneal (TEPP) hernioplasty - a case report. Int J Surg Sci 2018;2(1):33-6. [CrossRef]

12. Ansari MM. Optical illusions quintuple during laparoscopic total extraperitoneal preperitoneal (TEPP) TEPP hernioplasty - case report 2. JOJ Case Stud 2018;8(4):555745.[CrossRef]

13. Ansari MM. A Study of Laparoscopic Surgical Anatomy of Infraumbilical Posterior Rectus Sheath, Fascia Transversalis \& Pre-Peritoneal Fat/Fascia during TEPP Mesh Hernioplasty for Inguinal Hernia. Doctoral Thesis for PhD (Surgery), Aligarh Muslim University, Aligarh (India), 2016.

14. Ansari MM. Surgical significance of rectusial fascia during TEPP hernioplasty. Int J Sci Appl Res 2017;4(7):13-21.

15. Ansari MM. Complete posterior rectus sheath and total extra-peritoneal hernioplasty. Saudi Surgical Journal 2014;2(4):80-3.[CrossRef]

16. Ansari MM. Arcuate line of douglas: a prospective study of laparoscopic live surgical anatomy during TEPP hernioplasty. Int I Sci Res 2017;6(6):2348-63.

17. Ansari MM. Arcuate line variations: surgical significance and clinical implications during TEPP hernioplasty. J Surg Clin Interventions 2017:1(1):1-8.

18. Baumann (1940): cited by Diarra (1997).

19. Diarra B, Stoppa R, Verhaeghe P, Mertl P. About prolongations of the urogenital fascia into the pelvis: an anatomic study and general remarks on the interparietal-peritoneal fasciae. Hernia 1997;1:191-6. [CrossRef]
20. Walmsley $R$. The sheath of the rectus abdominis. J Anat 1937;71:40414.

21. MCVay CB, Anson BJ. Composition of the rectus sheath. The Anatomical Record 1940;77(2):213-25.[CrossRef]

22. Warwick $R$, Williams $P$ (eds). Gray's Anatomy. 35th ed. Philadelphia: WB Saunders, 1973.

23. Spitz JD, Arregui ME. Fascial anatomy of the inguinal region. In: Bendavid R, Abrahamson J, Arregui ME, Flament JB, Phillips EH (eds). Abdominal Wall Hernias: Principles and Management. 1sted. Chapter 8. New York: Springer Science-Business Media, 2001:86-91.

24. Ansari MM. Retzius space: not a single anatomical entity: new insights, simplified \& illustrated in a laparoscopic study during TEPP hernioplasty for inguinal hernia. Ann Intern Med Dental Res (AIMDR) 2017:4(1):SG63-73. [CrossRef]

25. Ansari MM. Retzius and bogros spaces: a prospective laparoscopic study and current perspectives. Ann Intern Med Dental Res (AIMDR) 2017;3(5):SG25-31. [CrossRef]

26. Anson BJ, Morgan EH, McVay CB. Surgical anatomy of the inguinal region based upon a study of 500 body halves. Surg Gynecol Obstet 1960;111:707-25

27. RizkNN. A new description of the anterior abdominal wall in man and mammals. J Anat 1980;131(3):373-85.

28. Rizk NN. The arcuate line of the rectus sheath-does it exist? J Anat 1991;175:1-6.

29. Mwachaka PM, Saidi HS, Odula PQ, Awori KO, Kaisha WO. Locating the arcuate line of douglas: is it of surgical relevance. Clin Anat 2010;23(1):84-6.[CrossRef]

30. Standring S (ed). Gray's Anatomy. 40th ed (eBook). Chapter 61. Edinburgh, London: Churchill Livingstone, 2008.

31. Saidi H. Endoscopic anatomy of the groin: implication for transabdominal preperitoneal herniorrhaphy. Anat J Africa 2012;1(1):2-10.

32. Rosen MJ, Petro CC, Stringer MD. Anterior abdominal wall. In: Susan Standring (ed). Gray's Anatomy: The Anatomical Basis of Clinical Practice. 41st ed. Chapter 61. UK: Elsevier, 2016:1069-82.

33. Condon RE. The anatomy of the inguinal region and its relation to groin hernia. In: Nyhus LM, Condon RE (eds). Hernia. 4thed. Philadelphia: Lippincott, 1995:16-72.

34. Cooper AP. The Anatomy and Surgical Treatment of Abdominal Hernia. London: Longman, 1804.

35. Moore KL, Dalley AF, Agur AMR (eds). Clinically Oriented Anatomy. 6th ed. Baltimore: Lippincott, Williams \& Wilkins, 2010.

36. Marks SC Jr, Gilroy AM, Page DW. The clinical anatomy of laparoscopic inguinal hernia repair. Singapore Med J 1996;37(5):51921. 


\section{ORIJINAL ÇALIŞMA-ÖZET}

Turk J Surg 2019; 35 (4): 299-308

\section{Posterior rektus kanalı: tek bir anatomik yapı ve morfoloji değildir-TEP hernioplasti sırasında laparoskopik inceleme}

Maulana Mohammed Ansari

Aligarh Muslim Üniversitesi, Jawaharlal Nehru Tıp Okulu, Genel Cerrahi Bölümü, Aligarh, Hindistan

\section{ÖZET}

Giriş ve Amaç: Posterior rektus kanalı, inguinal herni için total ekstraperitoneal preperitoneal (TEPP/TEP) hernioplastinin yeni laparoskopik teknikleri ile büyük bir önem kazanmıştır. Ancak, İngilizce literatürde posterior rektus kanalının canlı cerrahi anatomisinin bilimsel çalışması neredeyse hiç bulunmamaktadır ve bu çalışma bu sebeple gerçekleştirilmiştir.

Gereç ve Yöntem: Üç orta hat port tekniği yoluyla posterior rektus kılıfı yaklaşımı. Başta doğrudan $\mathrm{CO}_{2}$ insuflasyonu altında teleskopik diseksiyon ve ardından aletli diseksiyon.

Bulgular: Ortalama yaşı $50.1 \pm 17.2$ yıl (aralık 18-80) ve ortalama VKI $22.6 \pm 2.0 \mathrm{~kg} / \mathrm{m}^{2}$ (aralık 19.5-31.2) olan 60 hastada başarılı 68 TEPP hernioplastisi yapıldı. Rektus fasyası, geleneksel posterior rektus kanalı gerçek retromusküler alan ve gerçek posterior rektus kanalı (T-PRC) olarak adlandırılan iki kanala ayıran belirgin bir anatomik varlıktı. Rektus fasyası değişkendi; kalın yarı saydam ( $n=47)$, kalın membranöz ( $n=13)$, ince membranöz $(n=3)$ ve ince zayıf $(n=5)$. Posterior rektus kılıfı (PRS) da değişkendi: inkomplet $(n=54)$ ve kopmlet $(n=14)$. Inkomplet PRS hem derece hem de morfolojik bakımından yedi varyasyon gösterdi. Komplet PRS beş morfolojik varyasyona sahipti. Transversalis fasya tek yarı saydam ( $n=41$ ), tek membranöz $(n=10)$ ve ince zayıf $(n=3)$ olarak adlandırılan üç morfolojik varyasyon gösterdi. TEPP hernioplastisi, avasküler gerçek bir rektus kanal aracılığıyla kolaylıkla uygulanabildi.

Sonuç: Posterior rektus kanalı, rektus fasyası tarafından gerçek retromusküler alan ve gerçek posterior rektus kanalı olarak ikiye ayrılır ve sonuncusu TEPP hernioplastisi için uygun avasküler düzlemdir. Rektus fasya, posteriyör rektus kıllfı ve transversalis fasya morfolojik varyasyonlar gösterdi. Değişken gerçek zamanlı anatominin zamanında fark edilmesi kolayca, hızlıca ve güvenli bir şekilde TEPP hernioplasti için düzgün cerrahi diseksiyonun yapılabilmesi için önerilmektedir.

Anahtar Kelimeler: Laparoskopik hernioplasti, total ekstraperitoneal preperitoneal hernioplasti, posterior rektus kanalı, rektus fasya, posterior rektus kılıfı, transversalis fasya

Doi: 10.5578/turkjsurg.4334 